\title{
照明の演色効果における類似性と快適性 ${ }^{\dagger}$
}

\section{1. むえがき}

けい光ランプの照明の普及期にあたる昭和 26,7 年ご ろの照明学会雑誌を開いてみると, けい光ランプの光で は色が変わって見觉るという非難をあちこちに見い出す ことがでさる。扣もなものは，すき焼きの肉が腐ってい るように見える ${ }^{122)}$ ，まぐの刺身が灰色がかって見充 る13), 口紬の色がさえない゙, 顔色が黄色っぽく病人に 見える ${ }^{2)}$ ，比較的地味な赤と思って買ったネクタイが， 外で見ると意外に派手でしめられない4)などである.

なかでも『けい光灯下でオレンジがかった桃色で，何 ともい充ない良い色だと思っていたものが，自然光で見 直すと平凡なピンクに過ぎなかった』といらある婦人の 経験 ${ }^{4)}$ や『君，まぐろのさしみとすき焼きはけい光ラン プで食らベからずといらことを知っているか，腐った肉 みたいで食へないね』といらある据刻家の強硬な意見 ${ }^{3)}$ などには，当時の人々のけい光ランプの光に対する卒直 な意見がいきいきと表現されている。

現在でも, 一般の事務室, 工場, 住宅などには, ほと んど晋通形けい光ランプが使用されているにもかかわら ず，けい光ランプに対するこのような非難は今日ではあ まり聞かれないようである。

これは, 普通形けい光ランプの光のもとでの色の見兑 方に，われわれが 20 年ほどの間に十分に慣らされてし まって，けい光ランプはこのようなものだといら常識 が，いつの間にかできてしまっていることによるからで あろら。また，レストランや色物を报ら商店では，けい 光ランプと併用して電球を使用することが多く，印刷工 場の色の修正, 美術館の展示品の照明, デパートの唆服 売場などに，演色改善形けい光ランプが広く用いられる よらになったことも，理由の一つに上げられるである 万.

† Two Aspects for Appraisal of Color Rendition of Artificial Illuminants.

* 東京芝浦電気秝総合研究所

\section{正会員神部向 武*}

けい光ランプの分光分布を自然光に近づけると，ぼら しても效率が低下寸るため, 效率と演白性の両面から演 色改善形けい光ランプの分光分有を決めることが必要に なる。演色改善形けい光ランプの開発に詨して, 照明の 演色効果の研究の果たしてきた役制は大きい.

研究の初期には，日常のものの色がぞの程度に自然の 光で見たときと類似して見党るかを数量的にとら党よう とする立場の研究が多かったが, 自然光のもとでの色に とらわれずに，むのの色が美しく，多くの人に好杰れる 上うに見觉るためには, 光源の分光分布にどのよらな特 徽をもたせたら上いか，たとえば，顔色を美しく見せを けい光ランプが実現できないであろらか，といらような 立場からの検討もしだいに行なわれるよらになった。

これらの経過に関しては，すでに展望5)6゙なされて いるので，できるだけこれとの重複をさけて，われわれ が、これまでに行なってきた仕事に関連したものをけ心 に述べてみたい.

\section{2. 基準光に対する演色の類似性}

綿，葉たばこなどの農産物の等級付けに際して色は重 要な要因となるが，1940 年ごろには検査空の照明に自 然の光が利用されていた，日中でも季節や時刻により紧 度は大幅に変わるし，雨が降ったり夕暮れがせまると検 査を行ならことができなかった，当時，米国若務省の Cotton Division に席を执いていた D. Nickerson ${ }^{7}$ 《， 検查室の照明を人工照明飞拈き加点て，昼も夜もいつも 同じ条件で仕事ができるようにしたいと考学て，電球に ガラス・フィルタを組み合わせた光と, 自然の光の分光 分布を比べている.

このように，自然の光の代用になるような人工照明を 得ようとする際には, 自然光に対する演色効果の類似性 を確かめる手段が必要になる。

P.J. Bouma ${ }^{8)}$ は適当なつい立てにより，1枚の色紙 の半分を自然の光で照明し，他の半分を人工光源で照明 して，両者の演色効果の類似性を数段階のことばで表現 
する力法を用いた。この方法は，この直後に行なわれた けい光ランプの開発に利用されている ${ }^{910)}$. 図 1 は電

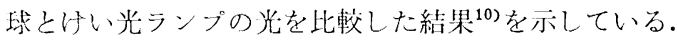
オストワルト色票の各色に対する演色効果が， 0 (Not Appreciable), 1 (Just Appreciable), 2 (Clearly Ap preciable), 3 (Very Striking, Quite Different Colour) の 4 段階のことばで表現されている.
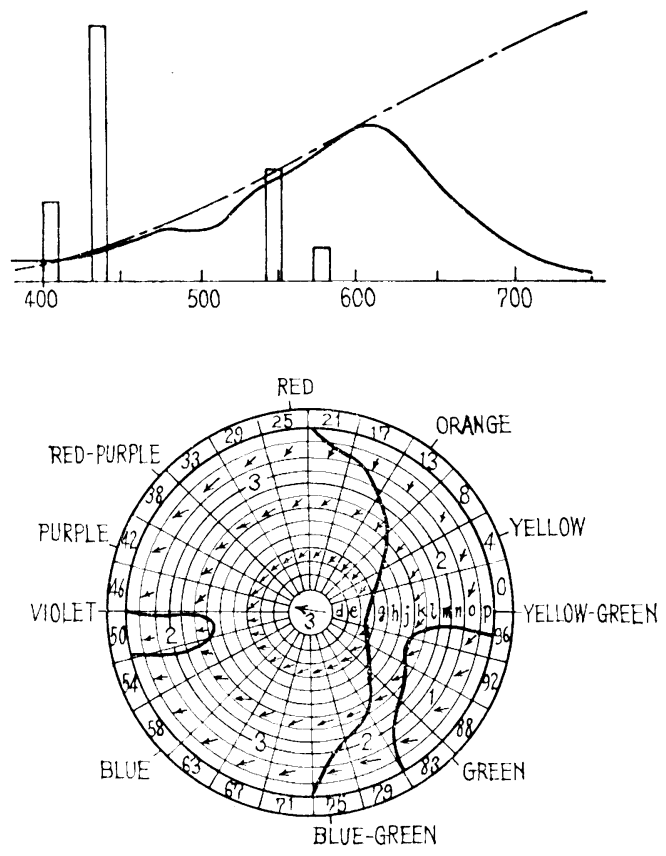

図 1 電球照明から $3,500^{\circ} \mathrm{K}$ けい光ランプ照明に 変之た場合のオストワルト色票の見之の変化 (Kruithof 10 ) )

困中の数字仕本文参照

この方法は，多くの場合に光色の異なる照明の演色効 果を同時比較することになるので，たとえば単独に照明 してその照明だけに十分順応した状態の演色効果に比べ て，照明の間の差が扩大されて感じられるといら欠点が ある. 最近では，このような同時比較は光色の近い照明 の比較に限られるようである ${ }^{11)}$.

I. Hennicke ${ }^{12)}$ は, 電球光代対してこれとほぼ同一の 光色の 6 種類のけい光ランプの演色効果の類似性を比較 する際に，図 2 の装置を用いて 継時比較の方法によっ ている，色票は灭色の背景上に提示され，電球照明から けい光ランプ照明に移り変わる祭は，色票は灭色の紙で 打扮われていて，数秒経過後にこれを取り除き，記憶し ている電球照明の色票の見えと比較して，5段階のこと ばで評価を行なっている，照明が変わる瞬間において色 の差が強調されて感じられることを避けたわけである。 色票上の照度は $501 \mathrm{x}$ である。4 種類の色票に対する 12 名の評俩の平均值と，色票の中から選ばれた 7 種類 の色票の基準光と試料光の間に計算される色差の平均值

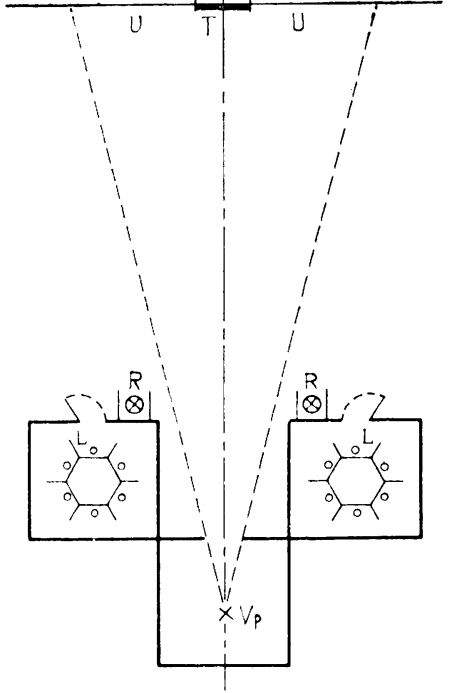

图 2 基準光亡陚料光の演色効果を継時的比比 較する場合の実駼装置 (Hennicke12)) $\mathrm{R}$ ：白熱電球 L : けい光ランプ $\mathrm{T}$ :色票 $\mathrm{U}$ : 背景 $\mathrm{V}_{p}$ : 被験者

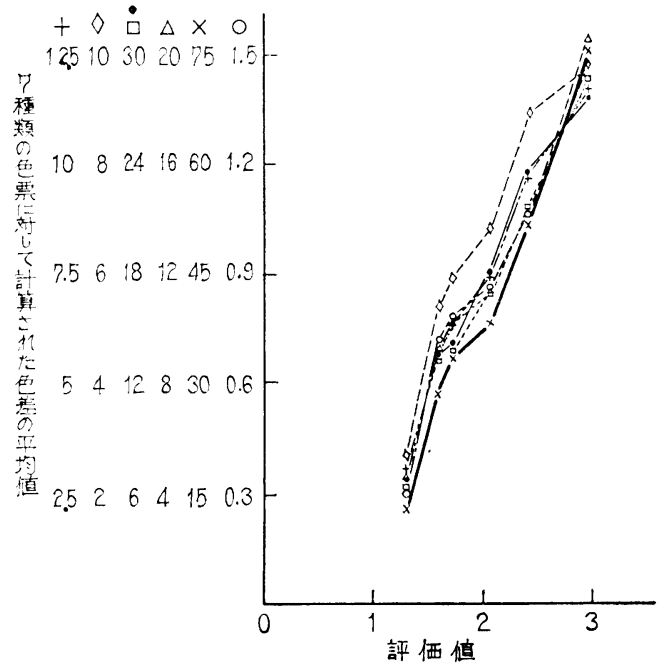

図 3 継洔比較の方法 (四 2 参照) で得られた類似 珄の評洒值と 7 種類の色票に対して基準, 試 料光間に計算される色差の平均优との関俰 (Hennicke) 12

困中の記号は 7 種類の色差式による結果に対他 している

とを比較している，色差を 7 種類の色差式で計算してい るが，図 3 に示すよらに，いずれの場合も相当よく一 致している。

この実験以前に, Barr, Clark and Hessler ${ }^{13}$, 東, 森 ${ }^{14)}$ によって, けい光ランプの演色効果の類似性を，光 色のほ涪等しい基準光との間に計算される色差から予測 する方法が提案されていた。この提案は Hennicke ${ }^{12)}$ の 実験による裏つけを得て，1963 年の CIE の会合で 1948 年の暫定的な勧告 ${ }^{15)}$ に代わって，正式に取り上げられる ことになった.この方法には基準光と試料光の光色がほ 
添等しい場合にだけ適用が限られるといら制約がある が，1964 年に CIEから勧告16)され，わが国に拈いても JIS ${ }^{17)}$ に採用されている.

Hennicke ${ }^{12)}$ の実験が，50 lx といら実際の照明と比べ てかなり低い照度で行なわれて㧍り，また電球と同じ色 温度のけい光ランプに限られているので，われわれは照 度 800 lxで，白色および昼光色けい光ランプ 7 種類を試 料光として Hennicke ${ }^{12)}$ の実験の追試を行なった ${ }^{18)}$. 基 準光には白色壮い光ランプとの比較の際は $4,300^{\circ} \mathrm{K}$ の 黒体放射に，昼光色けい光ランプとの比較には CIE の 定めた $6.250^{\circ} \mathrm{K}$ の標準的な昼光に分光分布と色度がな るべく近い照明を用いた. 図 4 にキセノンランブと色盜 度変換フィルタの組み合わせにより実現することができ た基準光の分光分布を示した。これらの照明の色度を図 5 に示す. 実験には, CIE の方法で色差の計算に用いる 試験色に分光分布のなるべく近似した色紙を用意した。

被験者は，両方が同時には見えないよらな位置に配置 されている基準，試料両光源のもとの色紙を交互に見比

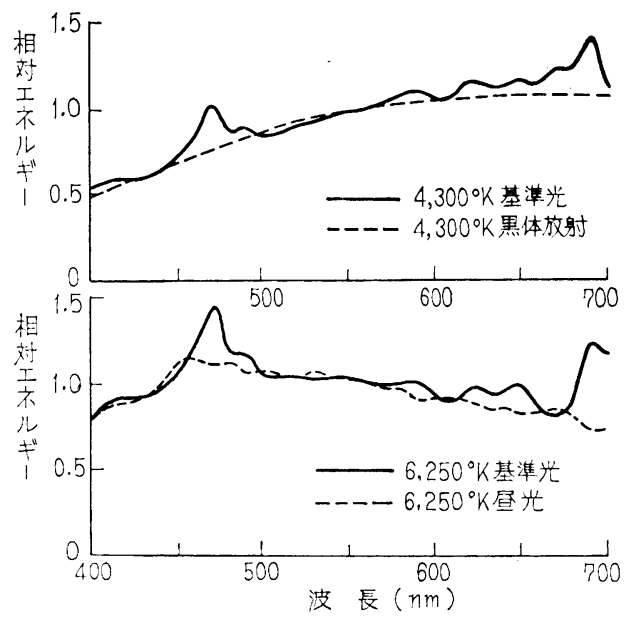

图 4 串験に用いた基準光 (実線) と CIE の方法 基活计万倠光（点線）の分光分布の比較 (神部, 森) 18

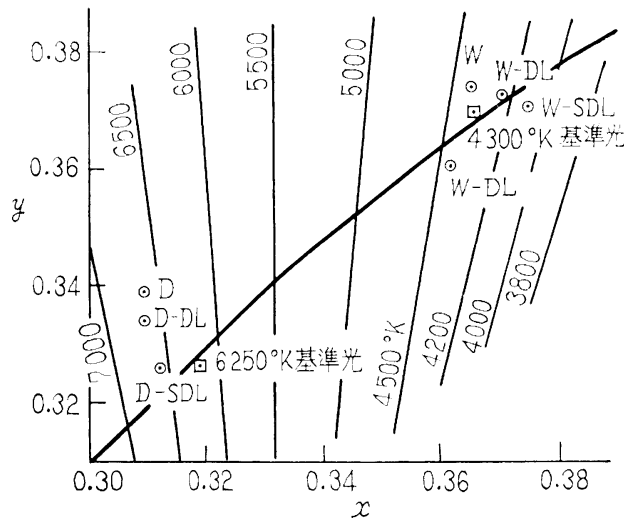

図 5 実験に用いた基準光と試料光の色度 (神部，森18)）
ベて，次の基準により評価を行なった。

（1）色の違いがわからない（0）

（2）ちょうど見分けられる程度の違いがある。（1）

（3）違って見えるが，日常の照明にはさしつかえた い. (2)

（4）違って見壳て，日常の照明には適さない。

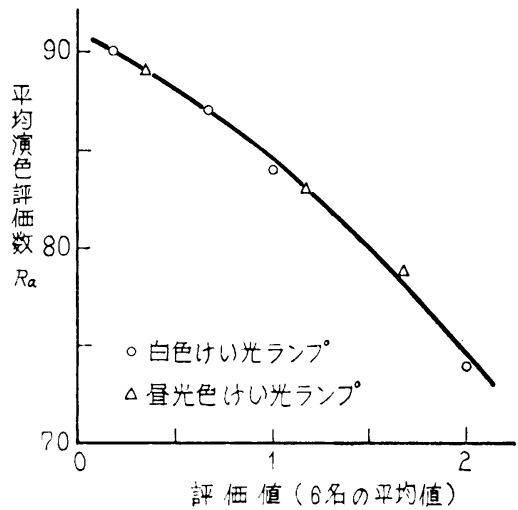

図 6 基準光に対する演色刘果の類似性の評洒 值と平均演色評価数（実験以用いた基準 光および試䮖色の分光分布に対して計算 したもの）との関係 (神部, 森18))

図 6 は，CIE の方法で平均演色評価数を算出する際 に用いる 8 種類の色紙を一列に並べた色票に刘して，6 名の被験者が行なった総合判定の平均值と，試料光の平 均演色評価数を比較したものである。

B. H. Crawford ${ }^{19) ~ 21) ~}$ は，類似性の程度をことばで評 価する代わりに，基準光自体の分光分布を除々に変化し ていって，記憶している最初の演色効果との差にはじめ て気づく分光分布の変化量を测定する方法で実験を行な っている。この実験では，照明のもとに置かれるのは色 紙ではなく，絵画，コーヒー，バター，レタス・にんじ ん・赤たいこんのサラダ，料理前の小羊の肉，鏡の中の 被験者自身の顔などである. 観察の際には, 照明の分光 分布は被験者の順応の経過を考えに入れて，ゆっくり連 続的に変えることが必要であるが，変化しはじめてから 演色の変化に被験者が気づくまでに, 約 3 分から 6 分程 度を要する変化の速さで，実験が行なわれているようで ある19)

Crawford ${ }^{20) 21)}$ はこの実験から，類似性の評価にあた って, 可視域の分光分布をスペリトル・バンドにくぎっ て，基準光と試料光の視感エネルギーの相対值を直接に 比較する方法を提案している。この方法の評価值は，さ きの Hennicke ${ }^{12)}$ の結果とよく一致すると Crawford ${ }^{21)}$ は述べているので，この実験は CIE の方法に対する実 験的裏づけを与える有力なデータを提供していると受け 取ることもできるであろう。

以上の実験は，いずれも基準光と試料光の演色効果を 
類似性の基準から比較判断している.この基準は Hennicke ${ }^{12)}$ の央験では数段階のことばの系列であり, Crawford ${ }^{19) \sim 21)}$ の実験では，演色の变化をはじめて感じ る場合の検出である。

いうまでもなく，この比較判断の基礎は，物体色の感 覚的な色の見方方である. 照明を変えた場合の感覚的な 色の見えの変化に関与る研究は，古くから行なわれてい る. Helson 22), Judd ${ }^{23)}$ の有彩色照明下の色票の見方方, Helson, Judd and Warren ${ }^{24)}$, Helson, Judd and Wilson $^{25)}$ の $\mathrm{A}$ 光照明, $\mathrm{C}$ 光照明およびけい光ランプ照 明のもとの色票の見え万などの実駼は，色相，彩度，明 度の各成分の主観的推定を被験者に一十分訓練して, 一種 の色名法で行なわれている.また Winch and Young ${ }^{26)}$, Burnham, Evans and Newhall ${ }^{27)}$, Wassef ${ }^{28)}$, Hunt ${ }^{29)}$ などの実験では，たとえば右眼ではA 光照明のもとに 打汀る色票を観察し，左眼では C 光照明のもとに打け るマンセル色票集の中の色票 ${ }^{2628)}$, あるいはC 光照明 の順応視野をもつ視感色彩計 27)29)を観察して, 两方の色 の見方方が等しくなるように色票集の色票, あるいは視 感色彩計を調整する万法が採用されている.

これらの史験の結果を利用して，感覚的な色の見觉を 基礎とした類似性の評価力法をまとめることができたな らば，基準光と試料光に光色の差がある場合の評価が可 能になるはずであるが，今のところこのような方法が成 功する見込久は立っていない，感覚的な色の見光は，照 明に対する目の順応のほかに，対象となる色のまわりの 色から影響を受けることが，この問題の取り扱いを相当 に困難なものにしている.

すでに別報 ${ }^{30)}$ に述べておいたよらに，視覚系の順応や 刘比の現熏に対して，われわれが持っている知識はまだ きわめて断片的なものにすぎない，これらの現象が十分 に解明されなくては, 照明のもとに扩尔色の見方方の 定量的な表現は可能にはならないのであり，現状ではわ れわれがこれを目標にかかげて, 照明の演色効果の類似 性に対する研究を進めることにさえも, いささかの疑問 を感じるほどである。

\section{3. 演色効果の快適性}

演色効果の類似性の基準からは，同等であると評価さ れる図 7 の二つの 分光分作のけい光ランプを住宅の居 間の照明に用いる場合に, どちらのランプのほうが快適 な照明効果を期待できるであろらか。図 7 の分光分布は Ouweltjes ${ }^{31)}$ が種々のけい光体の組み合わせで垁現でき る $4,200^{\circ} \mathrm{K}$ のけい光ランプを仮想的に計算した際のデ 一夕の中から, Jerome and Brewster ${ }^{32)}$ が平均演色評 価数の注注等しくなる組み合わせを探して，一つの困に まとめたものである．D. B. Judd ${ }^{33)}$ の計算によれば，

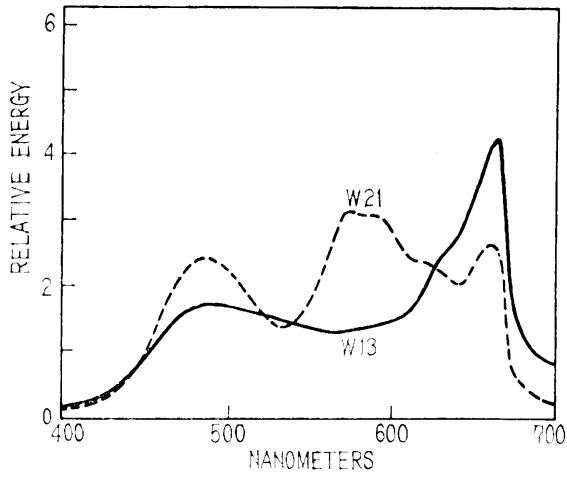

图 7 光色と平均演色評怵数の等しい二つの沛い 光ランプ $\left(4,200^{\circ} \mathrm{K}\right)$ の分光分布. ただし水 銀ラインは四から省略している (Jerome and Brewster 32 ))

$4,200^{\circ} \mathrm{K}$ の黑体放射を基準光として平均演色評価数を 求めると, W-13 のランプは 84.2, W-21 のランプは 84.6 となる. しかし， 10 種類の試験色に対する色度は 図 8 亿示与ように， $4,200^{\circ} \mathrm{K}$ の黑体放射の場合に比べ て方向が異なっている3 ${ }^{33}$.

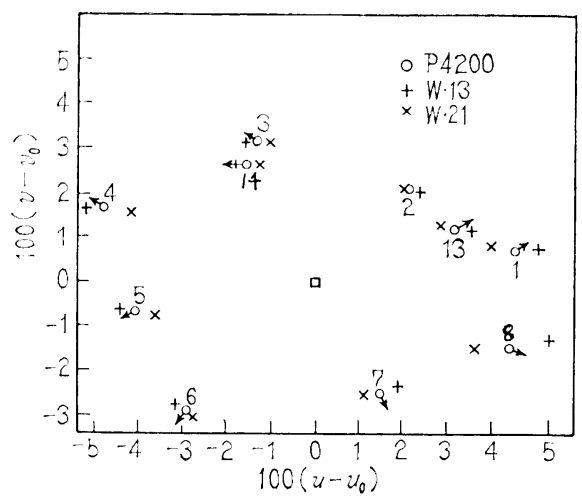

図 $84,200^{\circ} \mathrm{K}$ の 2 種のけい光ランブ (図 7 参照) および $4,200^{\circ} \mathrm{K}$ の黒体放射による 10 種類の 試験色の色度 (Judd 33 ) )

因中の矢印は Judd 34 ) の提案による演色効

果の上で好ましい色ずれの方向と色度を示す

$\operatorname{Judd}^{34)}$ は, 木の葉, 食物などの記憶色は一般に高彩 度の力向にずれるという Bartleson ${ }^{85)}$ の実験や，顔色， バタ一, ビーフ・ステーキなどの演色効果の好みを扱っ た Sanders ${ }^{36)}$ の実験を参照して，図 8 の矢印の方向に 色ずれを起こすような照明は，顔色や食物の見え力に対 して望ましい照明であると仮定することにより，矢印の 先端との色ずれを計算し，演色効果の快適性の評価值と したらどらかといら提案を行なっている， $4,200^{\circ} \mathrm{K}$ の 黒体放射の評洒值が 90 になるような尺度をとると, W13 のランプは 89.3に, W-21は78.1 となり, 前者に快 適性の面からはすぐれた評洒が与えられる。

Judd $^{34)}$ の提案は，同じ時期に行なわれた Pracejus ${ }^{37)}$ の実験からも支持されるようである.Pracejus ${ }^{37)}$ は央 
際に同一の室を二つ用意し，演色効果の快適性の比較を 試みているが，室内のインテリアを䁔色系と寒色系に統 一した場合の両方で赛験を行なった点に特徵がある.

Judd $^{34)}$ やPracejus ${ }^{37)}$ のように, 照明の分光分布だけ に注目して演色効果の快適性を取り扱らのが，唯一の方 法であろらか。冬の夜, 居間を, 日中北密からはいる自 然の光と同じ分光分布の光で照明したと仮定してみる と，この場合は相当照度を高くしないと，寒々とした感 じを消すことはできないであろら，もちろん，居間の照 度をこのように高くしたのでは，くつろいだいこいのふ んい気がそこなわれることも考光に入れなくてはならな w.

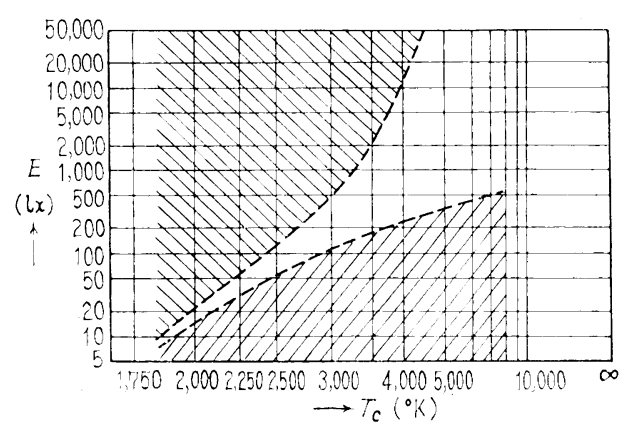

图 9 演色効果の快適性比刘与る照明の色温度女照 度レベルの涮係

(Kruithof ${ }^{10)}$ )

\section{A.A. Kruithof ${ }^{10)}$ は，実験室内の簡単な実験から図 9} の結果を得ている．低色温度では照度が低いと薄暗く感 じられて快適でなくなる，高色温度の場合は薄暗く感じ られるまで照度が低くなくても，ある一定の照度以下 では寒々とした感じになって，快適なふんい合ではなく なる。低色温度で照度が一定レベル以上になると色の見 えに不自然さが生じて快適でなくなるなどを指摘してい る.これは一般に照度が現在よりもかなり低く、けい光

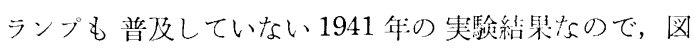
9 の照度の值は，そのまま現在にはあてはまらないので はないかとか，けい光ランブの普及により人《の照明の 色温度に対する感じ方も相当変化しているのではないか

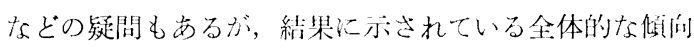
は多くの人が納得するところのよらに思われる*.

このよらに，演色效果の快適性には照度が大きな役割 を果たすので, われわれは牛肉, トマト, レモン, ピー マン, サボテン, りんどう(花), ききょう(花), 顔色 などを対象に実験を行なった ${ }^{38)}$. 実験は 2 回行なってい るが，はじめは $500 \mathrm{~lx}$ と $2001 \mathrm{x}$ の場合について 18 名（男 9 ,女9), 次は $1,000 \mathrm{~lx}$ と $100 \mathrm{~lx}$ について 10 名（男

* Kruithof ${ }^{10}$ ) の实験の追試には A. Wald : Li chttechnik. 5 (1953) 183, H. W. Bodmann, G. Sollner und E. Voit : CIE Vienne (1963) P-63-1 がある.
6，女4）で観察している. 評価は次の基準によった。

（1）非常に好ましい色汇見える。 $(+3)$

（2）かなり好末しい色注見える。(+2)

(3) やや好束しい色に見觉る. ( +1)

（4）好ましい色とも好ましくない色ともい充ない（）

(5)やや好ましくない色に見える. ( - 1)

(6) かなり好ましくない色に見党る．（一-2）

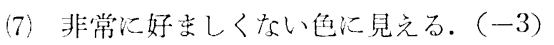
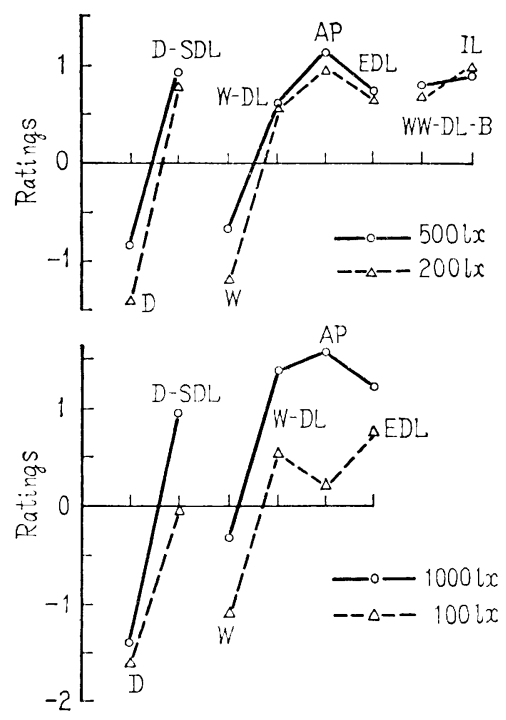

图 10 牛肉,トマト,レモン,ピーマンなどに刘

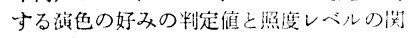
係 (神部, 金子-38)

図 10 K，食物，木の葉，顔色などの色の見え方の総 合的な印象に対する判定の平均值を示した。図中の記号 江, D (昼光色), D-SDL (真天然昼光色), W(白色), W-DL (天然白色), AP (真天然純正色, $5,000^{\circ} \mathrm{K}$ ), EDL（色評佃用純正色， $5,000^{\circ} \mathrm{K}$ ), WW-DL-B（天然 温白色， $2,600^{\circ} \mathrm{K}$ ) の夗い光ランプを示し，IL は白熱 電球である. 電球の照明の場合はけい光ランプ照明に光 の指向性を一致させるために，払散光による照明方式を 採用している。照明望切り换える祭には，品物を灭色の

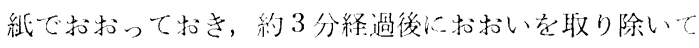
蜼価を行なった。

㠫度の影響は500 lx と200 lxで沈そら大きくないが， $1,0001 \mathrm{x}$ と $1001 \mathrm{x}$ の場合を比較すると $1001 \mathrm{x}$ では評㑣は 相当低下している．垁験では被験者をいくつかのグルー プに分けているが，同じ被験者が同じ日に二つ以上の照 度レベルにわたって評価を行ならことがないよらに計画 されている．絶詨判断によりこのよらな判定を行ならと きには，同じ実験系列内の照明の平均的な演色効果に㸚 して中位の判定が割り当てられる傾向がある。この类験 で5001x と $2001 \mathrm{x}$ の評価が変わらないからといって，こ の照度の差が快適性汇影響を与えないという結論にはな 
らない。照度の効果をこのような間接的な方法で比較し た理由は，直撄に比べたのでは，各照度レベルに十分順 応した状態で竦価を行ならためには実験に相当時間がか かること, 十分順応して実験を行なったとしても照度レ ベルの差が，头際に比べて強調されすぎることなどを考 光たためである。

快適性の評侕の場合にも, 類似性の判断と同様に, 判 断の基礎には物体色の感覚的な色の見え方が影響を与之 ているであろう。色の見方方は照度レベルによってどの ように変わるであるらか。この疑問值接答えるよう な奏験は，これまでにあまり行なわれていないよらであ る.照明された物体兒を直接に対象とした実験ではない が， R.W. G. Hunt ${ }^{39) 40)}$ はさきに述べた両眼間等色の方 法で，色刺激の見えおに及洼す順応耀度レベルの影響を 調ベている. 図 11 に亦す結果 ${ }^{40)}$ から, 順応輝度レベル

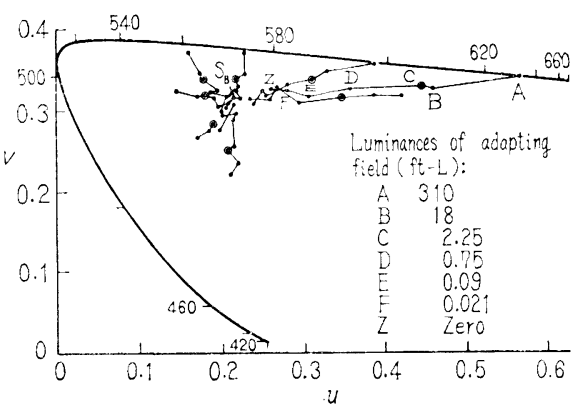

図 $11310 \mathrm{ft}-\mathrm{L}$ (A) から $0.021 \mathrm{ft}-\mathrm{L}$ (F) に至る刺 激の辉度レベルの変化に基づく同一色度のテス 卜色刺激の見か外の色の変容 (Hunt40)) 色剌激 $1^{\circ}$, 順底視野 $60^{\circ}$, デス卜刺湤之㮌底視野の 稙度は同一.たたし (Z) はテスト刺激 $0.021 \mathrm{ft}-\mathrm{L}$, 順庆視野は暗黑, Matching 剌激侧の順応視野の 輠度は $2.25 \mathrm{ft}-\mathrm{L}$ 一定, 順応刺溦の色度は図中の $\mathrm{S}_{B}$ に示与.

の低下にしたがって，色刺激から受计る感覚的なあざや かさの感じが低くなることがわかるであろら、われわれ も色紙の見光方について，Hunt ${ }^{39)}$ と同様な方法で垁験 を試みたが41)，照度が低くなると見かけ上の彩度の低下 とともに見かけの明度も低下して見えること，背景の明 度が見かけ上の彩度や明度の低下に対して，大きな影響 炎与宁ることなどがわかった。

快適性の評価を行なら際は，感覚的な色の見え方に対 して直接に評価を行ならのではなく，われわれの期待す る色の見方方に比べて，どの程度に満足できるかどらか という点に関して評価を行なっている，快適性の評価の 実験では，顔色，牛肉，りんご，バター，レタスなどの 自然の色が詨象に選ばれていて，ものによって少しぐら い色が変わっても許されるものと，少しの色の違いが非 常に強く印象一忛られるものがあるのは，このよらな理

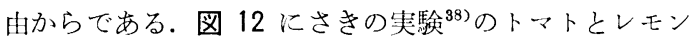

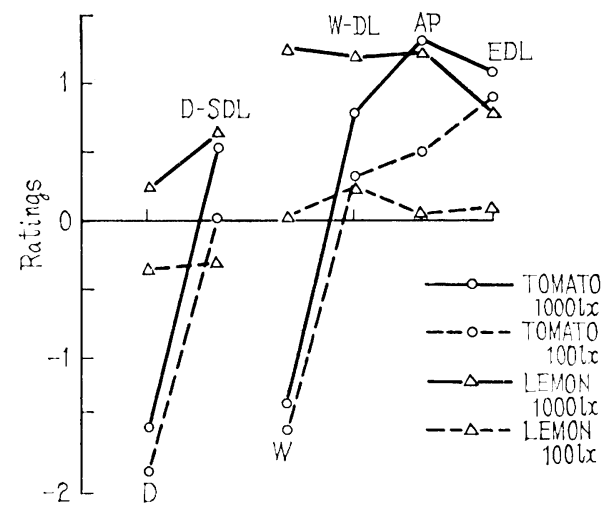

图 12 トマトとレモンに対与る治色の好みの判 定の比較 (神部, 金于 ${ }^{38}$ ))

に対する評価の結果を示した。トマトの評価は照明によ って変わるが，レモンではあまり変わらないことがわか る.

なかでも，いちばん問題になるのは顔色に対する評価 の場合である. Buck ${ }^{42)}$ や Einhorn and Naudé(3) の実 験でも，人によって好みの傾向が異なることが報告され

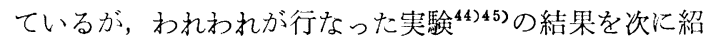
介したいと思う。

\section{4. 演色効果の好みにおける個人差, 顔色の 場合}

「たで食ら虫も好き好き」といらことわざが示すよら に，人の好みには個人差が大きいことはよく知られてい る。演色効果においても，人々の好みの違いを無視でき ない場合がある.

特定の男性をモデルに，照明を变えて顔色の見え力の 好ましさを 10 名（男 7 , 女 3 ）の人に観察してもらっ たことがある44).このとき 9 名の評洒はほぼ一致してい たが，1名の女性だけが他の人々の評価からはずれる傾 向を示すことがわかった．図 13 に結果を示す.

そこで女性 12 名に対して，さらにくわしく調べてみ ることになった ${ }^{445)}$. この場合は鏡で自分の顔を観察し た．照明が変わった後，1分間汪ど灰色の背景に順応し た後，次の基準で判定した。

顔色が自然の昼光のもとと比べて

（1）はっさり美しく見えるといえる. $(+2)$

(2) ぞちらかといらと美しく見えるよらな気がする. $(+1)$

(3) 変わらない（0)

(4) 悪く見觉るがこの程度ではがまんできる（（-1)

(5) 悪く見えて不満足である. (-2)

評価の傾向は次の 3 グループに分類できた.

グループ A：自然光に近い分光特性のランプおよび 


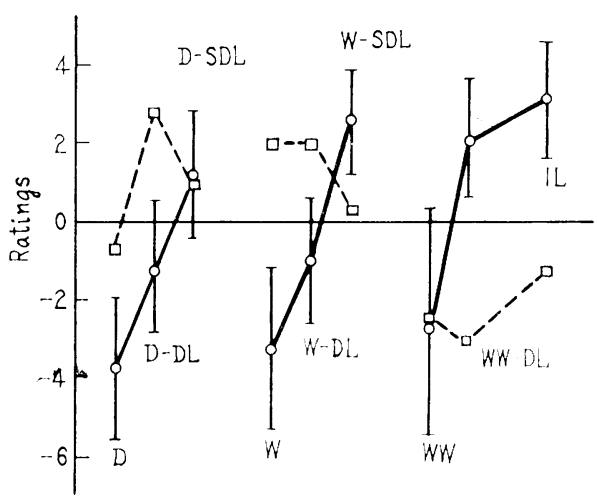

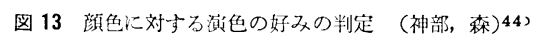
-○一：9名(男 7,女 2 ) の判定より Thurstone のカテゴリ判断の法則を仮定して算出した尺度值と

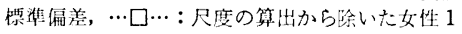
名の判定伯

電球による演色効果を好む。色温度は好みに影響しない (12 名中 5 名).

グループ B：ピンクがかった顔色の演色を好み，青 白いあるいは黄みを带びた顔色をきら5。色温度の低い シンブを好む傾向がある(12 名中 3 名).

グループ C：グループ $\mathrm{B}$ とほほ逆の傾向を示し，芯 温度の高いシンブを好み，色温度の低いシンブ，演色改 善形けい光ランプをさらら (12 名中 4 名).

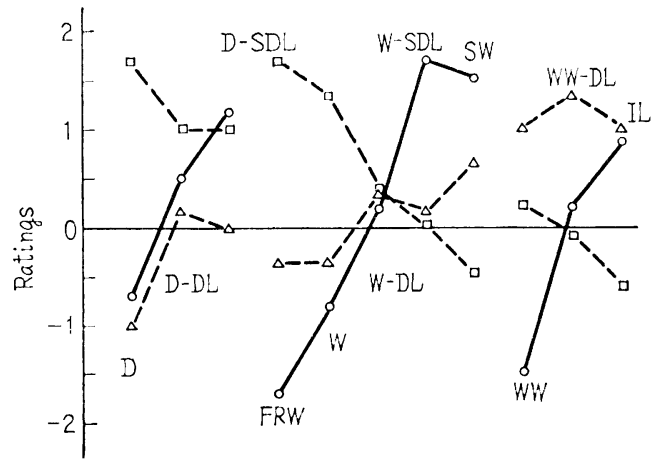

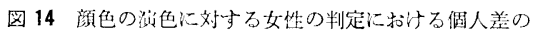
一例 (神部, 林44), Mori and Kambe 45))

$-O-$ : 被験者 $\mathrm{KK},-\triangle-$ : 被験者 TT $\cdots \square \cdots:$ 被験者 YS

図 14 K各グループから1名ずつの評俩を示した。被 験者 $\mathrm{KK}$ はグルーブ $\mathrm{A}$ を，TTはグループ $\mathrm{B}$ を， YS はグループ Cを代表する。横軸は色温度の近いものを 3 群に分け，さらにとの中を平均演色評価数の順に並心゙ た．実験は $600 \mathrm{~lx}$ と $300 \mathrm{~lx}$ の 2 条件で行なったが，図 には両条件の合計 6 回の判定の平均を示した。記号は, さきの実験で用いたものの汪かはD-DL (天然昼光色), FRW (明白色, $5,100^{\circ} \mathrm{K}$ ), W-SDL (真天然白色), SW (Soft White, $4,000^{\circ} \mathrm{K}$ ), WW (温白色, 3,000 $\mathrm{K}$ ), WW-DL（天然温白色， $3,000^{\circ} \mathrm{K}$ ) のけい光ランプを示
す. 電球照明の場合は, さきの実験 ${ }^{38)}$ 之同様に拡畋光で ある。

評洒の終わった後で，被験者にどのような照明を好ま しく思ったかを調查用紙に記入してもらった。たと壳ば 図 14 のグループ A の被験者 $\mathrm{KK}$ は『赤みがかった光の ほらが好ましい，青みがかっていても紫のかかったもの は（顔色を）美しく見せる. 緑のはいったものは不快感 を伴う．顔色が青くても不快でないものがある.』，グル ープ B の TT は『青白い光よりも，健康とうに見党る 光の汪らが好ましい。』グループCの YS は『赤及の ある光では（顔色が）きたなく見える，青みのある光が 美しく見せる.』と記入している.この記述の内容と図 14 の評価とはよく一致している.

人がもっとも敏感に識別できるのは，顔色のよいわる いであるといわれているが，女性の場合で特に自分の顔 色を対象としたときは，照明に対与る希望はこのように まったく逆のものを好さ人がある汪どに多様性に篦むも のなのであるふふだん青白すぎると思っている人は健尿 そらに見光る照明を好み，色が黑いことの父になる人梳 少しでも白く見えるような気がする照明を好むのである う. 実験に参加した日の化粈が，オークル系かピンク系 かによっても影響を受けるであろら。被駼者の顔の分光 反射率を測定して执かなかったのは残念である。

\section{5.むす び}

昭和 25 年, 当時はけい光ランプがわが国に扎いて一 般に使われはじめたころであるが，須田棟介氏12は次の ように述べている。『昭和 5,6 年のころだったと思うが フシンスの社交界では，そのころ披露宴などの招待状に はそこの会場の照明の光の色について注意が書かれて あるということを誰からか聞いたことがある.』化粧に も服装の色の配色にも，照明を考えに入れる習慣を持つ フランス人のセンスに比べて，わが国ではけい光ランプ の光があまりにも無神経な使われ方をしている当時の風 潮をなげいて，須田氏 ${ }^{1)}$ は『美しいものが，美しく見党 ないのは照明の欠陷である』と述べて，照明技術者の注 意を促している.

このときから 20 年を経過した今日，事態はどのよう に改善されているのであろらか.

住宅の居間の照明に，昼間，工場や事務室で働いてい るとさと同じ普通形けい光ランプの光が，形だけはサー クラインに変わっているが，平然と数やいているのが今 日の多くの家庭の垁状であるといっても，さしつかえは ないであろら。

住宅の照明には，心が安まるようなやわらかならんい 父がたいせつであって，明るくて経済的でさ充ればそ れでよいというものではないはずである. 
岡田喜義氏 ${ }^{46)}$ は演色がよいということの意味は『照明 によって得られる色彩環境が，照明飞用いる人々の期待 と欲求に適合して満足の程度が高いこと』でなければな らないと述べている.

照明飞対して，人々が期待する内容を照明技術者が把 握することはもらろんたいせつであるが，それだけで満 足しないで, 人々が期待し, 欲求する内容自体をさらに センスに富むものに変えていくといら役割も, 照明技術 者は自覚すべきであると思う。

照明の演色効果に対する研究も，これまでのように照 明の分光分布に限って，その色彩効果老扱うといら態度 から脱していく必要がある.たと党ば，顔色の見光力－ つを取り上げてみても, 照明の分光分布がまったく同一 でも, スポット・ライトによる発散光で照明する場合と

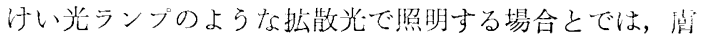
の光沢，透明さ，きめの細かさなどに微妙な差が生じる からである. 照明の演色効果には，このような微妙な差 がまたたいせつであることを深く認識すべきであろう。

終わりに，演色の㼋究にあたって日ごろご指導をいた だいている森礼於氏に厚く持礼总申し上活ます。

文献

(1) 須田棟介：照学誌 34 (1950) 243

(2) 藤田文太郎：照学誌 36 (1952) 84

(3) 山崎勝弘：照学誌 38 (1954) 319

(4) 森 礼於：照学誌 36 (1952) 299

(5) 森 礼於：色彩科学ハンドブック (1962) 337

(6) 森 礼於：テレビ学会誌 24 (1970) 647

(7) D. Nickerson : J. Opt. Soc. Amer. 29 (1939) 1

(8) P.J. Bouma : Philips Tech. Rev. 2 (1937) 1

（9）藤田文太郎，東 堯：照学誌 23 (1939) 230

(10) A. A. Kruithof : Philips Tech. Rev. 6 (1941) 65

(11) H. W. Bodman and B. Jacobson : Lichttechnik 11 (1959) 330

(12) I. Hennicke : Farbe 9 (1960) 183

(13) A. C. Barr, C. N. Clark and J. Hessler : Illum. Engng 47 (1952) 649

(14) 東 堯, 森 礼於 : 品学誌 38 (1954) 187

(15) CIE Compte Rendu (1948) 18

(16) CIE Method of Measuring and Specifying of Colour Rendering Properties of Light Sources, CIE Publication No. 13 (1965)

(17) JIS Z 8726 光源の演色性評価方法 (1967)

(18) 神部尚武, 森 礼於 : 昭 41 電学関西連大 (1966) 183
(19) B. H. Crawford : J. Opt. Soc. Amer. 49 (1959) 1147

(20) B. H. Crawford : Brit. J. Appl. Phys. 14 (1963) 319

(21) B. H. Crawford : Trans. Illum. Engng Soc. (London) 28 (1963) 50

(22) H. Helson : J. Exp. Psychol 23 (1938) 439

(23) D. B. Judd : J. Opt. Soc. Amer. 30 (1940) 2

(24) H. Helson, D. B. Judd and M. H. Warren : Illum. Engng 47 (1952) 221

(25) H. Helson, D. B. Judd and M. Wilson : Illum. Engng 51 (1956) 329

(26) G. T. Winch and B. M. Young : Illum. Engng 50 (1955) 353

(27) R. W. Burnham, R. M. Evans and M. Newhall: J. Opt. Soc. Amer. 47 (1957) 35

(28) E. G. T. Wassef : Optica Acta 6 (1959) 378 R. W. G. Hunt : J. Opt. Soc. Amer. 55 (1965) 1540

(30) 神部尚武：テレビ学会誌 23 (1969) 775

(31) J.L. Ouweltjes : Farbe 9 (1960) 207

(32) C. W. Jerome and E. W. Brewster : Preprint No. 12 of Conference of IES, Sep. (1967)

(33) D. B. Judd : Illum. Engng 62 (1967) 662

(34) D. B. Judd : Illum. Engng 62 (1967) 593

(35) C. J. Bartleson : J. Opt. Soc. Amer. 50 (1960) 73

(36) C. L. Sanders : Illum. Engng 54 (1959) 452

(37) W. G. Pracejus : Illum. Engng 62 (1967) 663

(38) 神部尚武，金子直礼：東芝レビュー 25（1970） 1228

(39) R. W. G. Hunt : J. Opt. Soc. Amer. 42 (1952) 190

(40) R. W. G. Hunt : The Reproduction of Colour, Second Ed., Wiley (1967) 124

(41) 神部尚武, 金子直礼：昭44 照学全国大会（1969） 52

(42) G. B. Buck II : Illum. Engng 45 (1950) 165

(43) H. D. Einhorn and D.E.H. Naudé : Trans. Illum. Engng Soc. (London) 28 (1963) 149

(44) 神部尚武, 森 礼於：昭 39 照学東京支部大会 (1964) 45

45) L. Mori and N. Kambe: Acta Chromatica 1 (1965) 181

(46) 岡田喜義：昭 38 連大S 6-3 (1963) 6 